\title{
MODERNITY'S DISAVOWAL: WOMEN, THE CITY AND THE DEPARTMENT STORE
}

\author{
Mica Nava \\ (c) 1997
}

[This article was published in: Modern Times: Reflections on a Century of English Modernity, eds Mica Nava and Alan O'Shea, Routledge 1996 and The Shopping Experience, eds Pasi Falk and Colin Campbell, Sage 1997]

\section{Introduction: a genealogy of absence}

This project started out as an investigation of the position of women in modernity. By focusing on shopping and the emergence of the department store as key iconic aspects of modern urban society my intention was to argue against those theorists who defined modernity of the late nineteenth and early twentieth centuries as a public stage from which women were excluded. However my attempt to integrate conceptualisations of modernity with questions raised by feminism and the culture of consumption revealed a surprising paucity of theoretical and historical work - a phenomenon which itself required explanation. Increasingly therefore my project was transformed into a genealogy of absence. It became, in addition to an engagement with existing debates and histories, an investigation into the often unconscious motives and priorities that operate in the production of intellectual work and that in this instance have led, I will argue, to the disavowal of a major narrative of twentieth century life.

\section{Modernity and women}

The argument for deploying the concept of modernity in order to make sense of the cultural and material changes which were accelerated in the major cities of the western world towards the end of the nineteenth century and the early decades of the twentieth century has been elaborated elsewhere (O'Shea, 1995). ${ }^{1}$ My particular focus is on the experience and representation of women, and, in this context, on the emergence of new forms of social interaction and perception and on the development of a new consciousness about the possibilities that modern urban life was able to offer. Modernity as I use it here - and I have produced a composite account for the purpose of this argument by selecting pertinent features from a range of contributions, both contemporary and more recent ${ }^{2}$ - highlights the complexity and danger as well as the richness and excitement of everyday life in the modern city. It draws attention to the texture of commonplace experiences in the metropolis, to an environment characterised by continuous flux and frequent encounters with strangers, in which signs and appearances acquire a new importance and substitute increasingly for traditional narratives of social and geographical belonging. There is a new stress on display and the visual - on looking. Modern urban existence, with its transience and uncertainty, demands new morals as well as new fashions. It produces new aspirations. It generates new enterprises, new languages and cultural forms. But modernity is not only about renewal. As a concept it also emphasises disintegration and fragmentation. It signals the destabilising of many nineteenth 
century conventions and highlights the pessimism as well as boldness of the modern imagination. And yet throughout it suggests a kind of forwardlookingness and a way, as Marshall Berman has put it, of making oneself at home in the chaos - 'the maelstrom' - of modern life, of becoming the subjects as well as the objects of modernisation (1984).

Modernity of course is a constructed narrative, and, like any other, offers us a version of events and the past in that it singles out certain phenomena for investigation or emphasis and ignores others. It is perhaps unsurprising to note therefore that despite the wide range of appropriations of the concept and its fertility in epistemological terms, it has failed on the whole to address the experience of women. In some of the classic accounts the prostitute or actress-entertainer is depicted as the characteristic female figure in the iconography of the urban landscape, in this way shoring up nineteenth century dualistic thought about virtuous and fallen women as well as mythologies of the sexually licentious city (Wilson 1991; Buci Glucksmann 1987) and at the same time ignoring ordinary women. Some of the more recent accounts have been even more neglectful, astonishingly so given the critical climate of the last two decades: Frisby for example refers not at all to sexual difference in his study of Simmel, Benjamin and Kracauer as key commentators on modernity, far less even than the authors did themselves when they wrote at the beginning of this century (Frisby, 1985; van Vucht Tijssen, 1991).

The project of academic feminism has been to prise open this sort of narrative and make sense of the marginalisation of women, both theoretically and historically wherever possible. Janet Wolff's influential 'The Invisible Flaneuse and the Literature of Modernity' (1985) has been the seminal piece on this intellectual issue $\mathrm{e}^{3}$ and the argument I develop here was generated in the first instance in response to hers. Wolff's thesis is that women are absent from the critical literature of modernity because its focus is largely upon the public sphere, on the crowded city street and the experience of the flaneur, on the world of politics and work - on areas from which, according to her, women were excluded. Hence their neglect by the theorists of modernity. Women's increasing confinement to the domestic sphere during the nineteenth century coincides with the development of the new discipline of sociology, which is concerned to classify and explain the changing phenomena of the modern public world. The more literary contributions also understand modernity as uniquely associated with the city and public life. Thus women's activities and labour, even where these are not confined to the home, are largely invisible. 'The literature of modernity ignores the private sphere and to that extent is silent on the subject of women's primary domain'(Wolff, 1985:44). Although Wolff acknowledges, though almost as an aside, that women are provided with a new public arena as a consequence of the emergence of the department store, ${ }^{4}$ her argument is that the characteristics of modernity identified by authors like Baudelaire and Benjamin, - 'the fleeting anonymous encounter and the purposeless strolling' - do not apply to women's activities. In sum Wolff's argument is that women were not only excluded from the literature of modernity but, confined as they were to the domestic sphere and the suburbs, women were also excluded from the experience of modernity. No female equivalent of the flaneur can be invented.

Although Wolff's article has made a valuable contribution by opening up the debate, there are nevertheless certain key assumptions in it with which I disagree. My argument will be that women were not excluded from the experience of modernity in the public sphere: that, on the contrary, they participated quite crucially in its formation. Indeed women's experience can be 
interpreted as a quintessential constituent of modernity. So we must look elsewhere if we are to understand the exclusion of women from the literature.

The reason that Wolff has argued otherwise is in part a consequence of her periodisation. The historical focus of her essay is on conditions during the second half of the nineteenth century, on those roughly contemporaneous with the 'early modernity' of Baudelaire, the period which Benjamin called 'the prehistory of modernity'. ${ }^{5}$ If she had periodised modernity differently and linked it to the drama of high modernisms, the expansion of mass culture and consumption and the sociopolitical instability of the late nineteenth and early twentieth century, her investigation would have encompassed the moment when women's appropriation of public spaces, in both symbolic and material ways, was growing rapidly. In this case, her argument about women's lack of participation in the experience of modernity would have been harder to sustain.

Another difficulty with Wolff's argument is that she depicts the 'flaneur' as the archetype of modernity. Here she reproduces the tendency in much of the literature to single out the artistobserver - 'the botaniser on the asphalt' (usually the author himself) - as the representative of the modern urban experience. In fact Baudelaire's flaneur - 'the painter of modern life' - was an observer and recorder of modernity, he did not exemplify it. Wolff's flaneur is moreover always a man because according to her argument only men have the freedom to wander at will and 'take visual possession of the city'. ${ }^{6}$ My argument will be that Wolff's concept of the flaneur, although productive for its emphasis on the ephemeral and the ocular - on looking - is limited insofar as it excludes the everyday spectatorship of ordinary people, and especially ordinary women.

In general Wolff's conclusions are representative of a rich but often pessimistic tradition in feminist historiography which tends to focus on the subordination of women and their marginalisation in mainstream historical accounts. ${ }^{7}$ Although these readings have had their political and theoretical importance, they have also inhibited the excavation of other 'truths'. Berman's emphasis on making the world your own, on the heroism as well as the despair of everyday life, offers the possibility of a different kind of interpretation of women's relationship to modernity, despite his own relative neglect of the issues. If Janet Wolff had been readier to focus on the expansion of women's cultural experiences in the city rather than on the constraints, then, paradoxically, she would have been in a position to advance more forcefully the second part of her argument, where she points to the invisibility of women in the literature of modernity.

But Wolff's process of deconstruction is not taken far enough. The absence from the literature is read as evidence of a 'real' absence rather than evidence of itself. A different reading of women's participation in modernity would have emphasised the constructedness of this literature. It would have highlighted the intellectual exclusion of women and the ambivalence of the authors about cultural change - the androcentrism of most of the texts about modernity. Janet Wolff's own argument about women's invisibility would have been rendered at once more complex and more persuasive.

These are the issues that are going to be developed in this chapter. The focus will be mainly on the department store and shopping in the urban context as an example of the way in which women engaged with the maelstrom of modern life. An exploration of this history will expand our understanding not only of the process of modernity but also, quite crucially, of the way it 
has been represented to us. In this sense it will be, as I suggested earlier, a kind of genealogy of absence. The question is: how can we make sense of the failure to acknowledge women's participation in the making of modern urban consumer culture - of the disavowal of this pivotal aspect of early twentieth century life?

One way of addressing this - even if not resolving it - is to look also at some of the formative popular and critical responses to consumerism and mass culture during the first decades of this century and to consider the ways in which the psychic and historical formations of authors inflect the texts that they produce.

\section{Women and the city}

It is important first to explore the symbolic resonance of the city in modernity and register its significance in relation to our objects of concern, to women, the department store and mass culture. More than any other social force of the nineteenth century, the city evoked the freedom as well as the menace that characterised the modern experience. Throughout this period it grew as a territory not only spatially but also in terms of its cultural significations, in the way in which it was understood and represented. The city was increasingly mythologised albeit in contradictory ways. The British version of this imagined geography tended to stress the disturbing aspects of the urban environment, the chaos and pollution, moral and sexual dissolution and the erosion of traditional order. ${ }^{8}$ In this narrative the threatening nature of the city regularly operated as a counterpoint to the ideal of a virtuous and harmonious rural or suburban domestic existence. ${ }^{9}$

This kind of polarisation (splitting and projection, in psychoanalytical terms) can be understood as an attempt to impose a moral and cognitive order on a highly volatile and incomprehensible geo-political context. It is also linked to the sexualisation of the symbolic register of the city. The position of women in nineteenth century urban mythologies was particularly charged (Walkowitz, 1980 and 1992; Wilson, 1991; Nava, 1984). Here too classifications of opposition and exclusion operated to maintain order. Disreputable women were associated with the immorality of public life in the city, with the despised prostitute and the unruly and often feminised urban mob (Huyssen 1986; Sennett 1977; Davidoff et al 1976). ${ }^{10}$ Respectable and virtuous women were connected to the home, and the ideal home was situated outside the city, in the leafy suburbs or village community. The sexual prohibitions and incitement elaborated in these discourses were marked by a deeply rooted conceptual and emotional adherence to the immutability of divisions - the fortified nature of boundaries - between women of different social classes and physical locations, and between the 'naturally ordained' spheres of men and women.

It has already been pointed out that much influential feminist historical research of the last decades (including Wolff's) has been concerned to trace the development of an ideology of separate spheres among the Victorian middle classes and has attempted to show how the cultural entrenchment of such ideas resulted in the social and material exclusion of women from public life and urban areas. This has undoubtedly been the dominant tendency in feminist historiography. ${ }^{11}$ However there have also been some dissenting interpretations. Amanda Vickery in her discussion of such positions has suggested 'the stress on the proper female sphere in Victorian discourse signalled concern that more women were active outside the 
home rather than proof that they were so confined'(1993:6). Elizabeth Wilson (1992) has also argued that women were not easily banished from public places, and Judith Walkowitz (1992) and others have drawn attention to the large numbers of middle-class women philanthropists who moved freely around the city streets.

These conflicting versions are evidence not only of current academic debate. They also suggest a much more uneven and contradictory picture of women's experience of city life than can be deduced from a face-value analysis of dominant discourses. Vickery's comment implies (though does not develop in this context) a reading against the grain, a reading which hints that the continuous reiteration of certain ideas might be evidence of anxiety and attempted denial rather than 'reality'. Moreover there is evidence that, during the closing decades of the century, there occurred increasingly in ideas about femininity and in women's circumstances precisely the instability and unfixing of parameters of difference that the concept of modernity as it has been used here seems to encapsulate so well.

One of the most significant changes that took place during this period was a rapid expansion of what counted as respectable, or at least acceptable, public space for unaccompanied women (Greenhalgh, 1988; Abelson 1989; Walkowitz 1992; Wilson 1991). The category included the great exhibitions, galleries, libraries, restaurants, tearooms, hotels and department stores (which will be returned to in more detail in the next section) - 'public-private liminal spaces' as Zukin (1988) has called them, associated in part with a more general promotion of buildings and events as cultural commodities and in part with the clear demands made by women themselves. A growing number of authors (but still a minority in the context of feminist debate) have described in detail the growth of these places and the ways in which they catered specifically to women visitors and clients. A significant but neglected consequence of this expansion was that middle class women travelled with increasing freedom through the streets and open public spaces of the city. They took advantage of all available forms of travel: some had their own carriages, others travelled by public transport - on trains, buses and tubes some rode their bicycles (during the 1890s there was a cycling craze for women) and yet others travelled on foot. ${ }^{12}$ Lynne Walker's research on this subject has shown how the private and public spaces that middle-class women frequented were often also within walking distance of each other and movement between them necessarily entailed mingling with the crowd and encountering strangers - possibly disreputable strangers - at close proximity. These forays were conducted on a daily basis for very many women. Several authors have drawn on diaries and correspondence to show the frequency and normality of such excursions, despite in some instances familial opposition and harassment on the streets. ${ }^{13}$ So what begins to emerge is a picture in which middle class women were much closer to the dangers and the excitement of city life than the notion of separate spheres would lead us to anticipate.

In fact middle class women laid increasing claim not only to 'respectable' public places. Large numbers also visited less salubrious neighbourhoods as part of the proliferation of philanthropic schemes that emerged during late nineteenth century in order to cope with the perceived crisis of the city - with the threat of social disorder, disease, destitution and inadequate housing. Middle-class women, as bearers of a particular kind of knowledge, were involved on a huge scale in the process of disseminating information about morality, domestic economy, hygiene and child care to women of the working class. In 1893 it was estimated that 20,000 women were paid officials and an astonishing half-million were voluntary workers 
engaged in philanthropic projects dedicated to improving the lives of the urban poor (Hollis 1979:226). ${ }^{14}$

So it is clear that middle-class urban women were not confined to their homes all the time. Indeed in their pursuit of 'adventure, self-discovery and meaningful work' (Walkowitz 1992:53) many would have ventured into slum territory unfamiliar even to their husbands and brothers. These journeys - which involved travel on public transport and on foot along unknown streets, and encounters in insanitary overcrowded housing with strangers possessing quite different life experiences - demanded from these urban explorers a quite extraordinary degree of intrepidity and yielded a rich store of personal and social discoveries. Women charity workers were engaged as much in a mapping of the new social relations of the city as were the more esteemed and recognised historians and poets of the moment. The visionary element in their activities was perhaps somewhat compromised by the fact that their personal freedom from the constraints of late Victorian domesticity was gained in the process of attempting to enforce it elsewhere, on the women of the poorer classes. But this contradiction need not undermine the modernity of their consciousness and experience any more than the contradictions of Faust's grand modern project as described by Berman (1983).

The women who travelled in this capacity, purposefully and relatively freely through the notorious streets of London, were unlikely to have lingered in parks and other public places to observe the ephemera of urban life - especially feminine life - in quite the voyeuristic style attributed to Baudelaire's flaneur. ${ }^{15}$ Nevertheless, charity work established for these women the right to look. It authorised the observation and classification of the homes, lives and even marital relationships of the poor. Middle-class women involved in the philanthropic enterprise were not obliged to conduct their affairs with lowered gaze. They could indulge the pleasures of urban spectatorship - of the voyeur - with a sense of entitlement which is not so easily distinguishable from that of the male flaneur. Moreover their participation in increasingly professionalised 'social' work also implicated them in the project of the regulation of populations - in the observation, correction and improvement of the social body - which is the central feature of Foucault's rather differently defined and periodised 'modernity'(Foucault 1980). ${ }^{16}$

Philanthropy is just one instance of the way in which the Victorian ideal of separate spheres was undermined, if somewhat contradictorily, and in the years around the turn of the century the numbers of women refusing to stay within the confines of the domestic expanded rapidly. Modern women were increasingly, if unevenly, engaged in the public world, in work, in financial transactions, in education and the dissemination of knowledge, and in political action. The movement for women's suffrage represented, perhaps more than any other activity, the spectacular high point of the early twentieth century challenge to Victorian conventions of femininity. During the years preceding the first world war many thousands of women from all social backgrounds took to the city streets in flamboyant, public and sometimes quite astonishingly violent protest against the injustice of disenfranchisement based on sexual difference. In 1908 it is estimated that as many as half a million people converged in Hyde Park to support (or observe) the struggle. The striking impact of enormously long columns of militant women marchers, progressing from all corners of London, dressed in the suffragette colours of white, green and purple and bearing thousands of boldly designed banners, is described by Lisa Tickner (1987) who argues that the campaign marked a significant turningpoint in the modern use of visual imagery and publicity. Moreover, in their articulation of a 
modernist imagination with political consciousness and a will to change, the protest marches for women's suffrage exemplify with extraordinary vividness the evocative concept of 'primal modern scene' developed by Marshall Berman to describe the archetypal or determining events of modernity in which the city streets become the stage for great moments of mass action and social transformation (1983:163). Berman, however, does not include the suffrage demonstrations among the historical events he selects to validate his category. So the campaign for votes for women is yet one more instance which demonstrates both the precariousness of nineteenth century codes of femininity and the narrowness of a notion of modernity which ignores the experience of women (Tickner 1987; Strachey 1978; Robins 1980).

This period also saw a destabilisation of Victorian sexual mores. There is a rich literature which situates the challenge to sexual conventions within the broader framework of the new woman's pursuit of fresh opportunities and greater social freedom. This challenge was posed not only in relation to choice of partner, courtship patterns and independence of movement. 'Free love' and the idea of sexual pleasure as an entitlement for women as well as men were gradually put on the agenda, albeit mainly in urban Bohemian and intellectual circles, and argued for alongside the need for sexual reforms like contraception and abortion. Despite the dangers of social ostracism and the continuing influence of social purity movements, the old sexual order was increasingly defied (Brandon 1990; Trimberger 1984; Showalter 1992; Sackville West 1983; Weeks 1981). Ideas about 'modern relationships' and new ways of living were slowly disseminated and popularised. Women's magazines and later the cinema were to be among the main sources of information about many of these questions for ordinary women. It was in these fora that women readers and spectators encountered representations of the new femininities, of vamps and independent women (Ewen and Ewen 1982). It was here that public discussion took place about the appropriate constituents of women's behaviour.

This section has set out some of the contradictory and unstable elements in city life and women's circumstances during the years around the turn of the century in order to provide a context for the ensuing study of early twentieth century cultural responses to women as consumers. What has emerged in this account is a dissonance between women's lived experience and the discourse of their seclusion in the domestic sphere. One way of making sense of this discourse is to see it as a form of denial, as a way of attempting to hold back the modern, of resisting - or at the very least of regulating - the encroachment of women, and the 'new woman' in particular. (We will see later that a similar process of denial operated in the public and critical responses to women's involvement in mass culture, particularly to shopping and cinema going). The turn of the century did indeed see an accelerating challenge to the rhetorical conventions of public and private spheres and to the distinctions between respectable and disreputable - to some of the major symbolic markers of sex and sexual identity. Insofar as modernity signals a permeability of boundaries and the blurring of categories and difference it seems untenable to argue that women were excluded from it. Furthermore, the women described here, in negotiating urban and political turbulence and challenging social orthodoxies, were engaged in the project of making themselves at home in the maelstrom of modern life, of becoming the subjects as well as the objects of modernisation, however contradictory, painful and uneven the process.

\section{Modernity and the department store}


Alongside these developments in personal mobility, urban spectatorship, political consciousness and social freedoms - and complexly related to them - was women's massive participation in the exploding culture of consumption and spectacle. It is here, in this arena, that the everyday lives of large numbers of ordinary women were most deeply affected by the process of modernity. The department store was from the late nineteenth century central to the iconography of consumer culture; it exemplified the ubiquity of the visual in the new 'scopic regime', and should be read as one of the archetypal sites of modernity which both produced and was produced by the experience of women (Falk 1996; Jay 1992). Emile Zola, in his carefully researched novel about late nineteenth century Paris The Ladies' Paradise, described such stores as a 'triumph of modern activity' (Zola 1992; Ross 1992). ${ }^{17}$

Shopping in fashionable city centres as a pleasurable social activity was already established among the upper classes prior to this period, as was the enhancement of social status and identity which derived from the consumption of intricately coded possessions and styles (Adburgham 1979; Campbell 1987; McKendrick et al 1982; Veblen 1979; Vickery 1992). In the late eighteenth century Oxford Street had already been described as a 'dazzling spectacle' of 'splendidly lit shop fronts' and 'alluring' and 'handsome' displays. In 1807 Robert Southey wrote of their opulence and social importance:

Shops are become exhibitions of fashion... When persons of distinction are in town, the usual employment of the ladies is to go a-shopping. This they do without actually wanting to purchase anything (Adburgham 1979:71-93).

As the century proceeded a number of factors combined to make the experience of fashionable shopping even more agreeable and to extend it to women of the middle classes, to 'democratise luxury' as Zola put it (1992). ${ }^{18}$ The expansion of shops and shopping during the latter decades of the nineteenth century and early years of the twentieth was due in part to a general growth in the economy and more specifically to developments in public transport, which benefited manufacturers as well as consumers and altered the spatial relations of the city. New forms of mass production of non-essential 'consumer' goods and ready-to-wear clothing also made a crucial contribution, as did the ambitions of individual entrepreneurs. The most significant factor however was probably growing demand. The aspirations of an expanding and increasingly socially and geographically-mobile urban population were inextricably bound up with the emergence and consolidation of modern forms of retailing, and the department store in particular Campbell 1987; Davis 1966).

Department stores were established in all the major cities of the western world and reached their 'zenith' (Adburgham 1979) during the period identified at the beginning of this chapter as the high point of modernity. Zola depicts the department store at the centre of his novel as a modern machine which devours the small outdated commercial enterprises surrounding it. According to him, department stores symbolise the 'forward momentum of the age: the bold new forms of capitalism'(Ross 1992). Their precursors, the covered shopping arcades of the mid-nineteenth century whose small specialty shops were unable to compete with massproduced commodities, are described by Walter Benjamin in his Arcades Project as an earlier form of capitalism: part of the 'ur-landscape of consumption' (Buck-Morss 1989:83). The new stores modernised retailing not only by offering a wide range of cheaper, mass-produced fashionable clothes and other commodities, but also by rationalising the use of space, making economies of scale, introducing clear pricing systems, and displaying goods in a safe and 
pleasant environment so that customers could look and compare without obligation to buy (Chaney 1983).

Linked inextricably to these commercial developments - and also a crucial component of the concept of modernity - was the growing importance of external appearances, of surface impressions. This concern for what Ewen has called 'armour for city life' (1988) was a feature of the specific historical conjuncture under review, which was characterised by an escalating instability of class and geographical boundaries. This increasing social fluidity is what fuelled Simmel's preoccupation with the meaning of modern fashions (1971). The period also witnessed the growing influence of a more open American culture, brought to Britain by developments in shipping and the mutual benefits of alliances between New World wealth and European 'distinction'. At such a socially precarious time, new signs were required as emblems of status and individuality. Dreiser's heroine Carrie (who at the beginning of the novel Sister Carrie published in 1900, seeks a job in a department store) exemplifies this in her meticulous acquisition and display of the codes of social position. Leonore Davidoff (1973) has shown how those aspiring to become part of Society in nineteenth-century Britain paid scrupulous attention to dress and comportment. During this period the fashioning of the home also gained significance as a visible indicator not only of rank but increasingly also of choice and 'identity' (Dreiser; Ewen 1988; Featherstone 1983; Forty 1986).

Women played a crucial part in the development of these taxonomies of signification - in the acquisition of goods which conveyed symbolic meanings about their owners - since it was women who went to the department stores and did the shopping. From their inception the department stores provided a particularly welcoming space for women and numerous contemporary accounts indicate that visits to them took place frequently, sometimes several times a week (Abelson 1989; Leach 1984; Walkowitz 1992). ${ }^{19}$ As institutions the stores made a major contribution to the twentieth-century consolidation of women as consumers and to consumption and consumer expertise as activities that were as gendered as production. ${ }^{20}$ During the period we are looking at women were confirmed as arbiters of taste and interpreters of the new - the modern. It was women who first of all encountered new fashions and domestic novelties and decided whether they were worth adopting. As those most literate in the complex signifiers of social hierarchy - a literacy acquired largely from magazines and the stores themselves (Breward 1994) - it was women who decoded and encoded the changing images of class. Within two or three decades these lessons were to be learned mainly from the movies - indeed Hollywood was to become a major inspiration for shop design (Eckert 1990) - but before the first world war, the principal source of information about the meaning of how others lived and dressed was found in the stores.

So clearly, department stores were more than just places where merchandise was bought and sold. In addition to facilitating the acquisition of 'cultural capital' (Bourdieu 1986) they formed part of the huge expansion of public space and spectacle which included the great international exhibitions, museums, galleries, leisure gardens and, a little later, the cinema, and they provided an extraordinary range of facilities, entertainments and visual pleasures. People visited them as tourist attractions - as monuments to modernity - for the interest and pleasure they afforded in themselves.

The historians of the most renowned department stores ${ }^{21}$ describe them as fantasy palaces. Increasingly purpose-built in the most luxurious styles with the most modern as well as 
traditional indigenous and imported materials, many had grand open staircases and galleries, ornate iron work, huge areas of glass in domed roofs and display windows, mirrored and marble walls, ${ }^{22}$ parquet floors covered with eastern carpets, and furniture upholstered in silk and leather. These emporia were among the very first public spaces to be heated and to use electric light not only for illumination but also for effect. In their display of goods and use of colour, they often drew on the conventions of theatre and exhibitions, continuously innovating to produce new, vivid and seductive environments, with mises-en-scene which combined, or offered in sequence, modernist, traditional and exotic decors (anticipating, or perhaps undermining, late twentieth century postmodernism). Rosalind Williams describes this constant renewal disdainfully as a 'hodge-podge of visual themes'(1982). However Zola's enthusiastic account of the exhibition of parasols in his (fictional) department store suggests a scenario which has been carefully designed:

Wide-open, rounded off like shields, (the parasols) covered the whole hall, from the glazed roof to the varnished oak mouldings below. They described festoons round the semi-circular arches of the upper storeys; they descended in garlands along the slender columns; they ran along in close lines on the balustrades of the galleries and the staircases; and everywhere, ranged symmetrically, speckling the walls with red green and yellow, they looked like great Venetian lanterns, lighted up for some colossal entertainment. In the corners were more complicated patterns, stars composed of parasols at thirty-nine sous, the light shades of which, pale-blue, cream-white and blush-rose, seemed to burn with the sweetness of a night light; whilst up above, immense Japanese parasols, on which golden-coloured cranes soared in a purple sky, blazed forth with the reflections of a great conflagration (Zola 1992:215).

These magnificent stage sets also served as backdrop to live entertainment which was provided on a regular basis. There were live orchestras in the restaurants and tearooms - and even, occasionally, in the grocery departments. Dress shows and pageants were regular occurrences. 'Spectacular oriental extravaganzas' which included live tableaux of Turkish harems, Cairo markets or Hindu temples, with live performers, dance, music, and of course oriental products, were also frequent events. It is interesting to note that during this period these exoticised yet commercial representations of 'oriental' imagery and narratives were a major source of popular knowledge about Empire, other cultures, and other aesthetic formations. Liberty's, which from 1875 specialised in Indian, Persian and Arabic merchandise and themes, was a pioneer in the development of this tradition. An example of Selfridges' 'cosmopolitanism', in which it took great pride, can be seen in Fig $1 .{ }^{23}$ Another recurring feature in the entertainment provided by the stores was the exhibition and deployment of the most advanced technologies. Rosalind Williams describes how in France new photographic techniques were used for cineoramas, mareoramas and dioramas to create the illusion of travelling not only in exotic places but also by balloon above the sea and to the surface of the moon (Williams 1982).

In addition to these visual experiences the department stores provided a vast range of facilities that enhanced the convenience, comfort and pleasure of shopping. These included supervised children's areas, toilets and powder rooms, hairdressing courts, ladies' and gentlemen's clubs and writing rooms, restaurants and tea rooms, roof gardens with pergolas, zoos and ice rinks, libraries, picture galleries, banks, ticket and travel agencies, grocery provision and delivery services. Standards of service were high and customers were made to feel welcome by obliging liveried doormen and deferential yet astute assistants. Alison Adburgham cites an 
article written by Lady Jeune in 1896 in which she comments on contemporary developments and in particular on the significance of the increase in women shopworkers:

two very important changes have contributed to the temptation of spending money nowadays. One is the gathering under one roof of all kinds of goods - clothing, millinery, groceries, furniture, in fact all the necessities of life. Nearly all the great shops in London are becoming vast stores. Many more people now come to London to shop and they prefer to make their purchases where they can concentrate their forces and diminish fatigue. The other is the large number of women now employed. Women are so much quicker than men, and they understand so much more readily what other women want. They can fathom the agony of despair as to the arrangement of colours, the alternative trimmings, the duration of a fashion and the depth of a woman's purse (Adburgham 1979:159).

So the department stores provided a source of employment for women as well as a welcoming place for them to shop.

The physical scale of these socio-commercial enterprises was huge. In 1903, Macy's restaurant in New York could accommodate 2,500 in one sitting. Harrods of Knightsbridge, which prided itself on being 'the most elegant and commodious emporium in the world' and 'a recognised social rendez-vous for members of Society' where it is 'perfectly proper for a lady to meet a gentleman', had at the turn of the century 6,000 employees and thirty six acres of shopping space organised into eighty different departments Adburgham 1989; Callery 1991). Selfridges, launched by the American entrepreneur Gordon Selfridge in 1909, was the first purpose built store in Britain and was even larger than Harrods. It distinguished itself from Harrods by targeting a more middle and lower-middle class clientele and offered 'bargain basements' from early on (Honeycombe 1984). Yet it too was designed to be a social meeting place and the public was encouraged to come and look without obligation to buy. The publicity slogans invited people to 'spend the day at Selfridges' and they did. 'It's so much brighter than their own homes. This is not a shop - it's a community centre', Mr Selfridge is alleged to have said, and kept the doors open till eight or later and the window-displays illuminated until midnight. The store was considered one of the great show sights of London, like Westminster Abbey, which all visitors from the provinces and abroad would expect to see. In the period prior to World War I, there was a relative scarcity of forms of public entertainment (cinema and radio were to take off later) and partly because the stores were open so far into the evening they did indeed become the entertainment centres and meeting points their founders envisaged. (See Fig 2 ) $^{24}$. Some anxiety was expressed by social observers and customers alike about the mingling of social classes within the confines of the stores and there were worries about the difficulties of 'placing' some young women shoppers and shop workers because of their respectable and fashionable appearances. ${ }^{25}$ Concern was also voiced about the possibilities of illicit encounters between men and women. Whiteley's of Bayswater had a 'reputation' in this respect, though what this signified in commercial terms is open to question. It is clear from the inaugural publicity of Selfridge's (as it was then called) that the possibility of 'pleasure' and 'recreation' in the company of a gentleman was deliberately presented as part of the allure of the store (Fig 3). ${ }^{26}$ So, in general, the blurring of class divisions and the relaxation of socio-sexual prohibitions, though in some respects risky, were considered necessary for the social appeal and commercial success of the stores and were likely to have been justified insofar as they were modern. 
Visiting the stores during this period became, then, an excursion, an exciting adventure in the phantasmagoria of the urban landscape. The department store was an anonymous yet acceptable public space and it opened up for women a range of new opportunities and pleasures - for independence, fantasy, unsupervised social encounters, even transgression - as well as, at the same time, for rationality, expertise and financial control. Shopping trips, sanctioned by domestic and familial obligations, justified, as did the philanthropic expeditions referred to earlier, relatively free movement around the city and travel on public transport in the proximity of strangers. The inspection of the merchandise on display in the shop windows was a necessary part of the activity so the streets and pavements in the main shopping centres were monopolised by women, ordinary middle-class women, part of the ebb and flow of the urban crowd, going about their business, or indulging their dreams, sometimes alone, sometimes with family or friends (see Fig 4). The department store, together with the proliferating women's household and fashion magazines and the popular story papers of that period contributed to the creation of modern female identities (Breward 1994; Melman 1988; Stein 1985). It facilitated the acquisition of consumer knowledge and enabled women to make informed and independent decisions about shopping. It also offered a language to imagine a different and better future, one in which the injuries and wants of everyday existence could be soothed and family lives enhanced. And in addition it provided a spectacular environment in which to stroll aimlessly, to be a flaneuse, to observe people, to admire and parade new fashions. This was a context which legitimised the desire of women to look as well as be looked at - it enabled them to be both subject and object of the gaze, to appropriate at one go the pleasure/power of both the voyeur and the narcissist (Nixon 1992). ${ }^{27}$

To draw attention to the exciting and empowering aspects of women's visits to the stores is not to deny that shopping can also be arduous; that anonymity and desire can be reread more negatively as loneliness and dissatisfaction. It is nevertheless to insist that the stores and shopping be recognised as one of the main contexts in which women developed a new consciousness of the possibilities and entitlements that modern life was able to offer. William Leach in his study of American department stores concludes thus:

In those early...euphoric days of consumer capitalism, textured so much by the department store, many women thought they had discovered a more exciting...life. Their participation in consumer experience challenged and subverted that complex of qualities traditionally known as feminine - dependence, passivity...domestic inwardness and sexual purity. Mass consumer culture presented to women a new definition of gender that carved out a space for individual expression similar to men's..(Leach 1984:342). ${ }^{28}$

Leach's article also elaborates on the connections between the department stores and early feminist organisations. In England, as in the United States, the highpoint of the department store coincided with the peak years of suffragette militancy. The owners of the department stores were well aware of the importance of the movement and several manufactured, displayed and supplied a wide range of goods - from tea services to outer garments - in purple, white and green, the symbolic colours of the struggle (Tickner 1987; Leach 1984; Lancaster 1995). They perceived their innovations in retailing as part of the same modernising process as women's emancipation and saw no conflict of interest between women's growing independence and the economic success of the stores. Harley Granville Barker's play The Madras House, originally published in 1911, includes among its characters an American department store magnate, Eustace Perrin State, who is an avowed supporter of what he 
refers to as 'the great modern women's movement'. 'A man who is not consciously in that movement is outside history' declares State. Having made a careful study of the issues involved in 'the women's question', he concludes that political claims for the vote constitute only a small part of it. In his opinion, 'the women's movement is (about) woman expressing herself'. His interest is not unrelated to his position as a store owner because, as he also points out, 'the economic independence of women is the next step (after their political freedom) in the march of civilisation'(Granville Barker 1977:83-88). ${ }^{29}$ There are plenty of 'real' as well as fictional instances of support, or at least acknowledgment, by the stores for the demands of feminism. Most overt was that of Wanamakers, the American store which gave all women employees time off during working hours to march in suffrage parades (Leach 1984). Restaurants in a number of stores in England became the meeting places of suffragettes during the period we are looking at. Fenwicks in Newcastle was apparently particularly well known for this. ${ }^{30} \mathrm{Mr}$ Selfridge was another example of a store owner who claimed to give support to the emancipation of women: 'I came along just when they wanted to step out on their own. They came to the store and realised some of their dreams' he is supposed to have said (Honeycombe 1984:24).

But consumption of course is about more than emancipation or the realisation of dreams or even politics. It is also crucially about work. Effective retailing is an absolutely integral aspect of modern capitalism. Without efficient marketing, which includes shopping, the production of goods ceases to be profitable. Yet despite the absolute centrality of consumption to modern western economic life, and despite the cultural and social resonance that I describe in this chapter, consumption as labour - unlike production - has until recently been remarkably neglected, both theoretically and politically. Shopping has been overlooked or trivialised by economists, sociologists, the left, and cultural theorists. As Grant McCracken has put it: 'The history of consumption has no history, no community of scholars, no tradition of scholarship' (1990:28). Shopping is also theoretically insignificant in the literature of modernity. Why should this be? ${ }^{31}$

\section{Shopping, the cinema and public anxieties}

In order to make sense of this historical neglect we must look at the broader context, at the ways in which shopping and a range of associated mass-cultural activities were perceived during this critical period. What emerges is a complex discursive formation composed of different strands - popular and intellectual - held together nevertheless by certain common anxieties which seem inextricably linked to the gendered nature of shopping. This is the context from which the seminal theoretical approaches develop and which goes on to shape the ways these processes have been more recently understood.

First of all, then, it must be noted that the expansion of women's social and economic activity in the public sphere as consumers came at the moment not only of growing suffragette militancy, but also when men's work as producers was increasingly subject to new forms of discipline and rationalisation, particularly in the United States though increasingly in Europe. This was the period of the emergence of 'Fordism', the assembly line, mass production and Frederick Taylor's theories about 'scientific management' which were designed to increase productivity by systematic observation and standardisation of human behaviour in the workplace. The implementation of Taylorism, which entailed a deskilling process as work 
became more routinised, inflexible and required less thought, was not confined to factories. It was applied increasingly to office work, retailing and the service industries, so rationalisation also affected the middle classes. The new systematised work processes were often resisted but the resulting increases in productivity and economic surplus led to higher wages for workers which enabled them to pay for the range of new commodities now available at lower prices on the market (Ewen 1976 and 1988; Gramsci 1973; Schwarz 1991; Wollen 1993). This increased ability to consume acted in effect as compensation for the greater monotony and duress of the workplace (Bauman 1983). Yet in its turn this compensation was undermined by the contradiction between men's work experiences and those of women, because precisely at the moment that many men were experiencing constraints in their places of employment, women were stepping out. The work that women were doing as consumers, unlike men's, continued to require substantial levels of skill and expertise and remained the one sector of the modern production-retailing cycle that was un-Taylorised and self-regulated. Moreover, this loose, undisciplined activity, although essential in terms of its economic productivity, often took place in the luxurious and symbolically resonant environment that I have already described.

The imagined freedoms and pleasures that these unsupervised excursions to the department stores offered, the ambiguous position of shopping as an activity which was neither clearly work nor leisure, and the financial control and social powers accruing to shoppers, together combined to generate a range of anxieties not only among the 'public' but also among those intellectuals whose ideas contributed to the formation of ideas about modernity and mass culture. Some of the anxieties to which I am referring surface and are easily identifiable in the contemporary accounts excavated by the historians of the stores. Others are more elusive and require different tools of analysis in order to make sense of them. The argument here is that all are associated in one way or another with the feminisation of consumption, with the fact that it was mainly women who did the shopping, and that the modern form of consumption was consolidated during a period in which earlier social conventions and boundaries appeared to be rapidly dissolving.

A number of authors have produced work from which contributes to the development of a sharper, more textured picture of the nature of the unease that seemed so pervasive and of the way it might have operated to deflect attention away from this particular aspect of commerce. The envy of men confined to routine Taylorised jobs in the face of the expanding liberty and responsibility that the new consumption entailed has already been argued for. Another less historicised way of explaining this envy can be developed by drawing on psychoanalysis. This is the approach of Rosalind Minsky who has explored the unconscious dynamic processes involved in the formation of envy provoked by the fantasised indulgence of desire and has argued that the sense of threat is constituted through the unconscious interpretation of the woman shopper as the pre-Oedipal phallic mother. ${ }^{32}$ This kind of account, which draws attention to the fear of dependence as well as greed, goes some way towards explaining the continuing ambivalence of many men, including academics, to the processes involved in shopping. A more historically grounded version (but not one which focuses on gender) is offered by Daniel Horowitz who investigates the shifts in the nature of the anxieties expressed about consumption in the United States between the late nineteenth century and the 1920s. During the earlier period, concern is oriented towards the dangers of profligacy, particularly among workers and immigrants. Subsequently the emphasis is on the dangers - the vacuity - of mass culture. Underlying both phases, he argues, is the fear of loss of self control in the 
pursuit of commodities and pleasures; this however sits uneasily with the recognition, current in the same moral discourse, that self-denial is not compatible with the imperatives of economic growth (Horowitz 1985).

Anxiety about the loss of moral and financial control generated by consumption is confirmed by Elaine Abelson who documents the increase in shoplifting by respectable middle-class women from the department stores during the same period (1989). Losses incurred thus were not inconsiderable: in 1905 in New York alone they were estimated to reach thousands of dollars a day. Yet prosecutions were often not carried out since many of the women were also valued customers, wives or daughters of men quite able to afford the price of goods that had been stolen. The inevitable publicity of legal action in such cases was considered counterproductive. The stores had to be careful to maintain their attractive image, to encourage desire, yet at the same time not permit uncontrolled illegal consumption. Men, not surprisingly, were anxious in case their womenfolk succumbed to the temptations of theft or unconsidered buying in the course of their socially sanctioned shopping trips. This is the context from which emerged the construct of kleptomania, considered from its inception to be an illness of middle-class women and associated specifically with department stores (Abelson 1989; Miller 1981; Zola 1992). Interestingly, a popular film of the period entitled The Kleptomaniac (dir.1905) addresses precisely this issue. It is about a wealthy woman guilty of stealing a decorative item from a store who is not prosecuted and a poor woman, guilty of stealing a loaf of bread, who is (Ewen and Ewen 1982:89). The contradiction inherent in the commercial practices of the department stores which on the one hand endorsed the creation of desire and on the other refused to prosecute 'respectable' customers guilty of theft is an example of the disavowal consumption seems to produce. It is also there in the contradiction highlighted by Horowitz between self-denial and spending.

Yet another reading of the ubiquitous anxieties associated with consumption can be elicited from the work of Stuart Ewen who emphasises the declining authority of fathers and husbands in the early decades of the century as women gradually enter the labour market and as their managerial status in the home is raised. Ewen understands this as a welcome diminution of patriarchal power (1976 and 1982). Less positive readings of the phenomenon are made by Christopher Lasch (1979) and members of the Frankfurt School and will be returned to in the next section.

Expressions of concern about the erosion of men's control over spending and money merge into much more overtly sexualised narratives. Elements of sexual fearfulness and rivalry surface in most of the accounts about women and shopping during this period. The department stores are accused of 'unleashing passions'. 'Temptation' and 'gullibility' become growing preoccupations. Anxieties are voiced about the 'intoxication' caused by the 'sensuous' display of goods. Zola talks about the 'longing covetous gaze' of women customers and the danger of being devoured by the 'erotic' and 'seductive' world of the store (1992). Miller in his account of the Bon Marche in Paris tells us of a woman who was alleged to obtain more 'voluptuous sensations' from the feel of silk than from her lover (1981:204). A few decades later women shoppers in the United States are represented as capricious and emotional, craving glamour and romance (Marchand 1986). Interestingly these sexual metaphors contain elements of both passivity and activity. On the one hand they seem to suggest the fear that innocent women will be seduced and ravished. On the other, that the stores will release an 
unbridled sexuality, an ominous transgressiveness. Zola represents his women sale-shoppers in this way, as part of an aggressive and sexually voracious mob:

The women reigned supreme. They had taken the whole place by storm, camping there, as in a conquered country, like an invading horde...(Zola 1992:236).

They advanced slowly...kept upright by the shoulders and bellies of those around them, of which they felt the close heat; and their satisfied desire enjoyed the painful entrance which incited still further their curiousity. There was a pellmell of ladies arrayed in silk, of poorly dressed middle-class women, and of bare-headed girls, all excited and carried away by the same passion. A few men buried beneath the overflow of bosoms were casting anxious glances around them...(Zola 1992:214).

The furs were scattered over the flooring, the readymade clothes were heaped up like the great coats of wounded soldiers, the lace and underlinen, unfolded, crumpled, thrown about everywhere, made one think of an army of women who had disrobed there in the disorder of some sudden desire (Zola cited by Ross 1992:xvii).

These descriptions not only refer us back to the fears of uncontainable sexuality that the urban context itself seemed to mobilise during that period (and that are alluded to in the section of this chapter on the city) ${ }^{33}$, they also evoke the way in which the crowd - the mob - has been recurringly feminised. Andreas Huyssen makes this point in the following way:

Male fears of an engulfing femininity are...projected onto the metropolitan masses, who did indeed represent a threat to the rational bourgeois order...The fear of the masses in this age of declining liberalism is almost always also a fear of woman, a fear of nature out of control, a fear of the unconscious, of sexuality, of the loss of identity and stable ego boundaries in the mass (1986:52-53).

It seems therefore that the loss of authority over women shoppers cannot be dissociated from the semi-conscious fear of their untrammelled sexual desire and of the potential eruption of social forces. And in fact some of these connections were fairly explicitly made. The desire of ordinary women for 'finery' in the late Victorian period was perceived not only an indication of sexual immorality but also as an attempt to rise above their station (Valverde 1989). The decomposition of the visible signs of class distinction that the department store offered, the continuous incitement of desire to possess commodities, the associated discontent and the promulgation of aspirations for a better life, did indeed represent a threat to the social order as well as, at the same time, a modernising force. Berman has pointed to the energy with which the bourgeoisie disrupted the earlier regimes (1983). In this instance the increasing and disturbing disintegration of social boundaries was produced by a contradictory alliance between modern capitalist methods of retailing and women consumers.

The anxieties about consumption and women shoppers that are outlined here have been deduced from a sparse literature. Commerce has not been considered worthy of much intellectual attention, as I have already pointed out, and so is not able to yield a theoretical commentary on the issues which is as extensive as that on other comparable aspects of mass culture. Cinema has produced the richest archive of comment and debate and it is from this source that it is possible to infer further evidence of anxiety about shopping as well as denial of its theoretical significance. Shopping, where it was referred to at all, was quite often associated with cinema-going in the period we are looking at. During the early decades of the century the cinema - like the department store - experienced a remarkable expansion. By 1909 there were over 340 movie houses and nickleodeons in New York City with an estimated two 
million visits per week. Paris had two cinemas in 1907 and by 1913 it had 160. In Germany the number of cinemas rose from two in 1900 to 2,446 in 1914. In Britain in the same year the number of cinemas was estimated at 4,000 with a weekly audience of seven to eight million (Ewen and Ewen 1982; Kuhn 1988; Mast 1982; O'Shea 1995; Ward 1991). The audiences who attended these movie houses - or 'dream palaces' as the agreeable new public social spaces were quickly to be called, echoing the language used about the stores - were composed, predominantly of women, young people and children. Seebohm Rowntree estimated in the $1930 \mathrm{~s}$ that $87.5 \%$ of all cinema goers fell into these categories (Richards 1984). ${ }^{34}$ During the daytime, audiences would have been almost exclusively made up of women and the young and women often combined their visits to the cinema with their shopping trips on their day excursions to the city centres.

The literature about this period of cinema-going indicates that there was widespread concern about the moral and physical consequences - particularly for the working class and the young of the content of films and the social and physical environment in which they were shown (Kuhn 1988; Mast 1982; Ward 1991). Concern about the specific influence of cinema-going on women has been less documented but is also likely to have been extensive, and indeed Miriam Hansen has argued, in relation to this conjunctural moment in Germany, that the resistance to cinema's cultural respectability was a consequence of the threat posed to the organisation of public space by the high proportion of women cinema-goers (Hansen 1983:735). Furthermore, women not only went to the cinema unaccompanied by men, once there they were not easily differentiated from each other in social terms: housewives, shopworkers and prostitutes sat as spectators in close proximity, blurring physically and metaphorically the boundaries between the respectable and the unrespectable.

It is certainly the case that 'passivity' and 'excessive excitation' appear as recurring preoccupations in much of the contemporary social comment about movie going and that these personal attributes contain some of the same gendered and sexualised connotations that are repeated in the discussions about women's visits to the department stores. Some of these connections between shopping and cinema-going are quite explicitly made; others remain more coded, to be uncovered in the course of a closer examination of critical responses to mass culture more generally. The explicit links, made here and there, are what enable us to make the leap into another discourse and assume that the structures of feeling displayed by some of the most influential commentators on cinema and mass culture during the first half of this century have something to reveal to us about how shopping was understood then, and continues to be understood today, in relation to modernity. A few examples from a small selection of key thinkers will trace this chain of cultural associations.

\section{Intellectuals, consumption and mass culture}

Louis Haugmard was among the first cultural critics to concern himself with the new form of cinema. In 1913, in his Aesthetics of Cinema (cited by Rosalind Williams 1982) he analyses the specific complexities of film as a medium and elaborates his condemnation of its social ramifications, its escapism and its ability to deceive the naive public. He is among those commentators who consider the movies emotionally over-stimulating and intellectually pacifying and he refers repeatedly to the 'excitation' and 'passivity' of cinema spectators. 
Moreover, and this is why his views are pertinent here, he makes a quite explicit connection between shopping and the cinema:

the passive solitude of the moviegoer resembles the behaviour of department store shoppers who also submit to the reign of imagery with a strange combination of intellectual and physical passivity and emotional hyperactivity (Williams 1982:82).

Siegfried Kracauer is another cultural critic who, over a decade later, echoes the approach of Haugmard in his piece entitled 'The Little Shopgirls go to the Cinema' and expresses similar fears about emotionality, passivity and receptivity and similarly connects the spheres of shopping and moviegoing - not only materially but also symbolically in the very title of his work (Kracauer 1987; Hake 1987; Petro 1987; Hansen 1983).

Kracauer was part of a circle of intellectuals, often loosely referred to as the Frankfurt School, which during the 1930s generated a number of seminal critiques of cultural and social issues. Over the last fifteen years, in the context of the emergence of cultural studies as an academic discipline, and with the translation and (re)publication of well-known and more obscure essays, the influence of the analytical approaches and concerns of those associated with the Frankfurt School has been consolidated and is now extensive. In this section I want to sketch out some of the suggestive connections and omissions which appear in this work and which support my general thesis about the anxieties of influential cultural thinkers about consumption. This method will inevitably be deductive, since questions of consumption and shopping are simply not raised in most of the debates about mass culture. So, in order to unravel what might have been thought, consciously or unconsciously, it will be necessary to read texts against the apparent intentions of their authors, to pursue insights across arguments and moments and refocus so that the historical and psychic context from which ideas emerge is scrutinised with as much attention as the ideas themselves.

A useful starting-point is Theodor Adorno and Max Horkheimer's critique of the culture industry, partly because of its status as a classic, almost iconic, piece of socio-political comment (1973). Adorno and Horkheimer, drawing on both American and German cultural examples, are deeply disturbed and angered by what they see as the banality of most mass culture - its dissipating amorphousness and triviality - and they too condemn the 'passivity' and lack of discrimination of the consumer. One way of making sense of what emerges from this text (sometimes only in quite coded form) as a virulent denigration of ordinary audiences, is to turn to the authors' work on the family, much of it written in the preceding decade while they were still in Germany (Horkheimer 1972; Jay 1984; Held 1980; Poster 1978). What emerges from this writing is a surprising nostalgia for an idealised family of the past and a sense of loss about the declining authority of the modern father in relation to his wife and children. Mass culture has threatened the potency of the father and displaced him as the socializing agent to which women and children now submit. The balance of forces within the family has been transformed. ${ }^{35}$ Ironically one way of reading these views is to see them as evidence of men's passivity as they witness the reorientation of women's desires away from the home to the seductive environment of the cinema and stores. Women's spectatorship in both these contexts is increasingly active and inquiring. Many men - ordinary members of the public as well as intellectuals - are threatened by their exclusion from the pleasures and knowledge that consumption offers. ${ }^{36}$ Mass culture emerges then as the despised yet alluring rival of the displaced man. The insistence of the cultural critics on the passivity of the consumer can be reread as denial, as a disavowal of the profound anxiety about loss and displacement that mass culture seems to engender. 
Andreas Huyssen, whose indicatively entitled piece 'Mass Culture as Woman: Modernism's Other' was referred to above in relation to the way the masses have been feminised, explores in the same article the way mass culture likewise has been intricately bound up with pejorative notions of the feminine (1988). ${ }^{37}$ Mass culture moreover also takes on the attributes of the (feminised) masses, that is to say it is frequently depicted as engulfing, irrational, sentimental and so forth. Thus it is contrasted not only with masculinity but also with cultural modernism, which is hard, rigorous and rational, and which has always been concerned to distance itself from the popular. Interestingly for my argument here, Huyssen points out that Adorno, Horkheimer and Kracauer each, at different times, explicitly sexualises and engenders mass culture. For example Adorno and Horkheimer argue that mass culture 'cannot renounce the threat of castration' (Huyssen 1988:48). ${ }^{38}$ Adorno, of course, is also known for his defence of modernism and high cultural aesthetics against the encroaching contamination of mass culture. Huyssen's argument about the feminisation of mass culture, and mine about mass culture and consumption as the rival of the male, are obviously different, yet they are not incompatible. Indeed paradoxically they confirm and complement each other methodologically. Both operate in symbolic registers - as metaphors - and centre-stage the way in which unconscious processes are at work in the formation of intellectual positions. Both insist that these must be rooted in specific historical contexts and narratives.

Walter Benjamin is another influential contributor to the debate about mass culture. His uncompleted and largely unpublished Passagen-Werk (The Arcades Project) reconstructed and developed with extraordinary insight and elegance by Susan Buck-Morss (1989), ${ }^{39}$ is one of the few attempts to theorise the significance of shopping arcades in relation to modernity and commodity capitalism and, in conjunction with his other work on culture and cinema, continues to have a profound influence on contemporary debates. In the context of the argument which is being put forward here, Benjamin must be distinguished from other associates of the Frankfurt School. His criticisms of mass culture are, at least in some places, far more tempered and complex and he argues for the aesthetic and political possibilities of popular cultural forms. ${ }^{40} \mathrm{He}$ is not only less pessimistic about mass culture and the advent of modernity - about 'modernity's rupture of tradition' - he also welcomes the decline of 'the antiquarian effect of the father on his son'. Buck-Morss puts it thus:

In a world of objects that changed its face drastically in the course of a generation, parents could no longer counsel their children... The rupture of tradition was irrevocable. Far from lamenting the situation, Benjamin saw precisely here modernity's uniquely revolutionary potential...The rupture of tradition...frees symbolic powers from conservative restraints for the task of social transformation...Benjamin insisted: "We must wake up from the world of our parents." (Buck-Morss 1989:279).

Nevertheless, his Arcades Project is also at the same time full of a deeply felt ambivalence about the temptations of the metropolitan world of consumption and spectacle - the urban phantasmagoria - which both dazzles and deceives the crowd. The world of commodities is about illusion. Value is eclipsed by representation and display. Benjamin is simultaneously fascinated and guilty, both lustful and repelled by the luxury and decadence of city life. As Elizabeth Wilson has suggested, his views are at once utopian and dystopian (1992). He is also manifestly ambivalent towards women, where he considers them at all. ${ }^{41}$ In most of Benjamin's work it is the prostitute who is presented as the key female figure in the iconography of the city, and at the same time, as the embodiment of commodification. In Passagen-werk he 
argues that women use fashion to cover up the 'reality of natural decay', that fashion 'encourages the fetishistic fragmentation of the living body'. We see here the association Benjamin makes between women, commodities and consumption. Women, like commodities, are about surfaces and illusion. Yet among his notes for Passagen-werk, and once more indicative of his contradictory feelings, he suggests also that fashion can be 'irreverent towards tradition....and emblematic of social change' (Buck-Morss 1989:101). ${ }^{42}$

This major work is a unique yet contradictory and fragmented attempt to understand consumption. The ambivalence to commerce which is expressed throughout can, I think, be traced in part to Benjamin's recurring preoccupation with generational difference and his frequently documented conflicts with his own father, a financier who invested in innovative urban projects, among them a department store and ice rink. Some of what Benjamin considered his formative commercial and erotic experiences are recounted in his autobiographical essay 'A Berlin Chronicle':

I was most lastingly affected... when in about $1910 . .$. my father conceived the idea of taking me to...The Ice Palace [which was] not only the first artificial ice rink to be seen in Berlin, but also a thriving night club...My attention was held...by the apparitions at the bar. Among these was a prostitute in a very tight-fitting white sailor's suit, who determined my erotic fantasies for years to come...

In those early years I got to know the 'town' only as a theatre of purchases, [where]...my father's money cut a path for us between the shop counters and assistants and mirrors, and the appraising eyes of our mother, whose muff lay on the counter. In the ignominy of a 'new suit' we stood there, our hands peeping from the sleeves like dirty price tags, and it was only in the confectioners that our spirits rose with the feeling of having escaped the false worship that humiliated our mother...Caverns of commodities - that was the 'town'(Benjamin 1986a:39-40).

Hannah Arendt in her introduction to the collection of Benjamin's essays Illuminations discusses the insolubility of the Jewish question for Jewish intellectuals of Benjamin's generation "because all traditions and all cultures as well as all "belonging" had become equally questionable to them' (Arendt 1973:36). This refusal of tradition casts additional light on Benjamin's hostility to what his parents represented, to commerce and thence his route to 'commodity fetishism'. ${ }^{43}$ Demetz interprets the conflict slightly differently:

In many Jewish families of late nineteenth-century Europe, gifted sons turned against the commercial interests of their fathers, who were largely assimilated ...to bourgeois success, and, in building their counterworlds in spiritual protest, they incisively shaped the future of science, philosophy and literature. Articulating an insight of far-reaching implications, Karl Kraus, the belligerent Viennese satirist, suggested in his Magical Operetta (much enjoyed by Benjamin) that little Jewish family dramas were being played out all over, the stern fathers concerned with...business and the spiritual sons with...the less profitable matter of the pure mind (Demetz 1986:ix). ${ }^{44}$

Among such sons, Demetz includes Freud, Husserl, Kafka and of course Benjamin himself, for whom 'the fundamental pattern reasserts itself with particular clarity' (Demetz 1986:ix). ${ }^{45}$

Benjamin's antagonism towards his parents - and his father in particular (referred to in his own autobiographical work as well as in the biographical accounts of Arendt and Demetz) contributes to our understanding of his refusal (unlike Adorno and Horkheimer) to lament the decline of paternal authority in the family and helps explain his 'forwardlookingness', his 
optimism about the possibilities of the modern. A connection can also be made between his ambivalence towards commerce - his simultaneous fascination and repudiation of the 'theatres of purchases' and 'caverns of commodities' that 'create false worship' - and the anti-Semitic climate of central Europe in the 1930s described by Gregor von Rezzori in his Memoirs of an Anti-Semite in which 'Commerce per se was embarrassing... anything connected with selling in a store was below social acceptance. This was a privilege of the Jews' (von Rezzori 1983:86). The humiliating anti-Semitic targeting of commerce, about which Benjamin must have felt enormously contradictory, was actualised during the period of his immersion in the writing of Passagen-Werk by the officially authorised Nazi boycotts of Jewish-owned department stores in Berlin, which, in April 1933, were among the first propaganda assaults of Hitler's newly elected government (Fromm 1943; Frei 1987).

These contextual factors help to make sense of Benjamin's equivocal and uncompleted analysis of consumption as well as his orientation towards the future - his modernism, in Berman's terms. They do not though explain his lack of serious attention to the ways in which consumption is gendered, to the ways ordinary modern women might be placed in relation to the modernity and shops he so meticulously represents. This omission, this failure to explore the significance of the feminisation of such a crucial aspect of commodity capitalism and mass culture must also be understood (like the similar omissions of other intellectuals of this and earlier periods) in the context of the broader social and psychic transformations of the period. The shifting balance of forces between men and women in the family and the growing independence of women have already been referred to. This period was also affected by the traumatic and dehumanising slaughter of the first world war. Challenges to the constraints and conventions of femininity reached a particularly frenzied pace during the interwar years and meshed with anxieties about the demographic crisis and the numerical disparity of the sexes resulting from the war. Concerns about 'superfluous' women - who in the popular imagination were also 'new' women: flappers, hedonists, feminists, workers, voters - can be read as evidence of a crisis of masculinity, of men's fear of being diminished, swamped and consumed (Melman 1988; Kohn 1992). Klaus Theweleit (1987) has analysed the cultural dread of dissolution and engulfment exhibited during this period in the writing and fantasies of German Freikorps soldiers who were later to become the vanguard of the Nazi party. He makes the point that some of these fears are articulated by men of the left as well. It would not be surprising therefore - in a context in which additionally, German socialist feminism was still robust and the Weimar Sex Reform movement, designed to address the sexual interests of the new woman, had a membership of 150,000 (Grossmann 1984; Thonnessen 1973)) - to find a certain ambivalence about women and a certain blindness about the feminisation of mass culture and consumption in the work of the cultural critics of the period.

\section{Conclusion}

One of the innovations of feminist thought has been to alert us to the unpredictable and covert ways of the symbolic world. It has encouraged us to pose different kinds of questions of texts, authors and social processes. In this piece of work, my project has been to excavate the different contexts in which influential ideas about women, modernity and consumption have developed and to refocus theoretical investigation onto gaps and inflections as well as emphases. What has emerged from this research is a history pitted by ambivalence and denial. Modernity as a narrative and experience has turned out to be far more profoundly marked by 
the material and imagined presence of women than the classic accounts have allowed. Yet, consumption, the sphere in which women's participation has been so culturally and economically definitive, has barely been addressed by the academy. ${ }^{46}$ What I have tried to argue here is that this discursive marginalisation must be understood partly as a consequence of the association of consumption with the destabilisation of nineteenth century femininities and the emergence of the new woman. Uneasy public fears provoked by these shifting cultural patterns and the fantasised loss of control incurred in visits to the department stores, meshed in complex ways during the early part of this century with intellectual ambivalence about mass culture and disdain for commerce. This mood, the cultural formation that I have identified here, is deeply implicated in the construction of views about consumption. It has led to the repudiation of shopping and shoppers and a denial of the theoretical centrality of women to the making of modernity. 
1.This article was originally written for a book produced by members of the Department of Cultural Studies at the University of East London entitled Modern Times: Reflections on a Century of English Modernity eds Mica Nava and Alan O'Shea (1995); as the title indicates, modernity was the organising principle. Alan O'Shea's introductory chapter 'English Subjects of Modernity' sets out the argument for the theoretical usefulness of the concept. My thanks to all the contributors to that book for their helpful and comradely comments on earlier drafts of this piece. The story started here is continued in Nava (1995) 'Modernity Tamed? Women Shoppers and the Rationalisation of Consumption in the Interwar Period'.

2. Among the authors and texts I have drawn on for the purposes of my argument are Anderson (1984); Baudelaire (1965); Benjamin (1973 and 1986a); Berman (1983 and 1984); Bradbury and McFarlane (1987); Buck-Morss (1989); Frisby (1985); Lash and Friedman (1992); Sennett (1986); Simmel (1971); Williams (1989); Wilson (1991 and 1992); Wolff (1985 and 1990).

3. The article was first published 1985. A slightly revised version appears in Wolff (1990). Janet Wolff has recently reiterated her support for her initial argument (1993).

4. The reprinted version of this article (Wolff, 1990) includes a slightly longer comment on this subject than the original. See also Wolff's essay 'Feminism and Modernism' in the same book.

5. This is despite the fact that she also draws on theorists whose major concern was with the social transformations which took place later, at the end of the nineteenth and beginning of the twentieth centuries (for example Thorstein Veblen and Georg Simmel) in order to support her argument.

6. Elizabeth Wilson's phrase (1992:98). Wilson is more sceptical than Wolff. For her the flaneur is a powerless and marginal figure, a loiterer-voyeur in the urban labyrinth.

7. Her reliance on Thorstein Veblen for the development of her comments on consumption confirms this approach. For a critique of Veblen's analysis see Grant McCracken (1990) and Amanda Vickery (1992).

8. See Davidoff et al (1976); Marriott (1995); Nava (1984); Rose (1979); Stedman Jones (1976); Walkowitz (1992); Williams (1975); Wilson (1991). Twentieth century British versions are also more pessimistic: see for example the debate between Berman and Anderson in New Left Review in 1984; and the ideology of the garden city and slum clearance movements (Wilson 1991).

9. European and American accounts of the city, although often ambivalent and concerned about the destruction of traditional values and modes of living, were also less fearful and more inclined to welcome - even celebrate the rich and complex phantasmagoria of the modern metropolitan landscape. As Elizabeth Wilson has pointed out (1991) in Paris whole families were likely to enjoy the cafe life on the broad new boulevards, while in the United States the city came increasingly to represent a modern architectural and social ideal. See also eg Theodore Dreiser's novel Sister Carrie, first published in 1900 (1981).

10. Huyssen also quotes Gustave Le Bon: 'Crowds are everywhere characterised by feminine characteristics'(1986:52).

11. Janet Wolff is the one to have made the link to modernity and it is repeated in several of her essays, see for example 'The Culture of Separate Spheres: The Role of Culture in Nineteenth-Century Public and Private Life' (1990). Other feminist historians have also explored the separate spheres of men and women, at least as an ideal, see for example the extensive and important contributions of Leonore Davidoff and Catherine Hall who stress the material interdependence of the 'public' and the 'private' during the first half of the nineteenth century (1987). See also Jenny Ryan for an example of a feminist historian whose emphasis is predominantly 
on the constraints of separate spheres and on the patriarchal exclusion of women from the public domain (1992)

12. Lynne Walker, 'Women and Victorian Public Space', paper given at 'The Cracks in The Pavement' conference at the Design Museum, London, 1991. Walker showed a slide of two women in the 1890s travelling on the underground with their briefcases. Adburgham (1989) refers to the cycling craze and the new fashions that were required for it.

13. See eg Abelson (1989) and Leach (1984) for the United States and Adburgham (1989) and Walkowitz (1992) for England, particularly London. See Walkowitz (1992:50-52) for a discussion of male pests and sexual harassment.

14. See also Addams (1910), Banks (1981), Nava (1984), Wilson (1978), Walkowitz (1992).

15. See Wilson's discussion of the arguments made by Wolff (1985) and Pollock (1988) (Wilson 1992).

16. See also Donzelot (1979) who draws on Foucault and explores the shift in philanthropy from the gift of charity to the rendering of advice.

17. The quote from Zola's notes is taken from Ross (1992). Zola's novel was originally published in 1883.

18. Schudson (1984) has suggested that this should be understood as a democratisation of aspiration and envy. For the expansion of consumer culture into the middle classes see also Abelson (1989) and Chaney (1983).

19. Among the first public toilets for 'ladies' were those provided by the department stores, obviously an added incentive.

20. It is generally estimated that $80 \%$ of purchasing decisions today are made by women and that this has been the case since the beginning of the century at least, see Pumphrey (1987) and Marchand (1986). Women were certainly identified with the internal decor of their homes and were responsible for design and domestic shopping decisions from the mid-nineteenth century onwards (Forty 1986). Men seem never to have been very comfortable in department stores except as sellers, and even here their importance declined from the late nineteenth century onwards (Adburgham 1979; Lancaster 1995). Abelson (1989) claims that $90 \%$ of visitors to the stores in America during this period were women.

21. There were of course regional and historical variations. Not all were as glamorous as those described here. Some were modernised while others were built from scratch. Provincial and suburban stores were oriented towards a different clientele. Yet all were designed to be attractive and make women feel welcome. The account I present here is a composite based on the research of Abelson (1989); Adburgham (1978 and 1989); Bowlby (1985); Callery (1991); Covina (1978); Davis (1966); Honeycombe (1984); Lancaster (1995); Leach (1984); Miller 1981); Moss and Turton (1989); Williams (1982); Zola (1992).

22. The Ladies Club at Harrods was panelled in Brecchi Sanguine, Pavannazi and Levantine marbles and onyx according to Harrods publicity material of 1910 (Callery 1991).

23. One of the posters in 'The Spirit of Modern Commerce' series produced by Selfridge's to mark the fifth anniversary of its opening which celebrates 'the Romance that lies in Commerce'(held in the store's archive). This poster is also interesting for its text (unfortunately not legible in this reproduction) particularly in relation to the argument I develop later in this piece of work. Written by German industrialist Herr Rudolph Hertzog, it is a comment on the important place of the merchant in the life of the people both at home and abroad, and attempts to analyse the lack of regard with which 'princes of commerce' are viewed compared to land owners, even by their own sons. See note 45 for further discussion of this aspect of Hertzog's comments. 
24. Selfridges archive. Fig 2 ('Selfridge's "at home"') was one of a series of full-page advertisements which appeared in the London daily papers in March 1909 to mark the opening of the store (Selfridges archive). The full text reads:

We are always ready with a welcome to strangers within our gates. We bid them feel at home and endeavour in every way imaginable to create and cherish that comfortable sentiment. Reception Rooms are open to them in which to meet their friends. Name Registers in the National Rooms will enable them to record their own advent and tell them of home acquaintances who may also be in London. The Library is available for correspondence and the Post Office for mailing it. The Silent Room is eloquent of quietude. Retiring Rooms are many and perfectly appointed. If our visitor is a Gentleman the Smoke Lounge is suggestive of a meditative weed. And these accommodations belong to visitors without fee of any kind whatever and without the remotest obligation in their use to make a purchase.

The Parcel and Cloak Room takes charge of all impediments. The Bureau de Change will negotiate letters of credit. The Information Office will answer accurately any reasonable question. Seats at all theatres can be booked, and Railway and Steamship tickets taken to anywhere without going outside our doors. The Luncheon Hall and al fresco Tea Garden serve appetising teas and luncheons in dainty home-like fashion at moderate charges: and from floor to floor, through the hundred or more departments, are displays of Manifold Merchandise incomparable in richness, utility and quality at London's Lowest Prices always.

25. The stores also provided significant career and income opportunities for women. See Lancaster (1995); Leach (1984); Zola (1992).

26. One of Selfridge's promotional advertisements for its launch in 1909. Selfridges archive.

27. See also Mica Nava and Rosalind Minsky (forthcoming) 'Women as Rational and Irrational Shoppers'.

28. This is a contentious reading of course. Cultural analysis, particularly of the left, has a well established convention of seeing commodity culture as irredeemably bad. Richards' eloquent critique of advertising and the growth of mass consumption is an example of this (1991). See also the discussion in 'Consumerism Reconsidered: Buying and Power' (in Nava 1992).

29. Thanks to Peter Horne for alerting me to this play.

30. Lancaster (1995) cites David Neville's MPhil 'Women's Suffrage on Tyneside' University of Northumbria, as source of information about Fenwicks in Newcastle.

31. See also Nava (1992) chapters 8 and 10. Consumption as an area of theoretical study is now finally expanding quite rapidly. Among significant contributions to the literature not cited elsewhere in this article are: Carter 1984 and 1995; Morris 1988; Mort 1988; and Shields 1992.

32. Nava and Minsky, 'Women as Shoppers'.

33. Wilson (1991) explores the associations between the city and seductive but threatening sexualities.

34. The Seebohm Rowntree survey reported that $50 \%$ of cinema goers were young people and children, and of the remaining adults, $75 \%$ were women (Richards 1984). Such precise information about the earlier period is not available.

35. Lasch makes exactly the same point (1979:74) and similarly bemoans these transformations.

36. See again Minsky's section in Nava and Minsky, 'Women as Shoppers'. 
37. Huyssen's article was originally published in Modleski (1986b). For a complementary analysis which looks at the feminisation of mass culture see Modleski (1986a).

38. Modleski makes a similar point about Jean Baudrillard's ambivalence towards these issues. For him, she says, 'the masses function as a "a gigantic black whole", a simile ostensibly taken from physics, but perhaps owing something to (feminine) anatomy as well' (1986a:48).

39. See also Buck-Morss (1983); Brewster (1968); Benjamin (1968; 1973; 1986); McRobbie (1992); Wilson (1992); Miller (1995).

40. See for example 'The Work of Art in the Age of Mechanical Reproduction' in Benjamin (1973).

41. Susan Buck-Morss makes very little reference to this in either of her discussions of Passagen-Werk (1983 or 1989). But see for example Benjamin's autobiographical 'A Berlin Chronicle' (Benjamin 1986a). See also his Moscow Diary (1986b) in which he constantly reiterates his ambivalence towards Asja Lacis, the woman he travelled to Moscow to see. The theme of this relationship, according to Gary Smith, is 'drawn as an erotic red thread throughout Benjamin's journal, (it) is one of obsession and denial' (1986:141).

42. See Berman (1984) and Gaines (1990) for further discussions of Benjamin's unease.

43. See also Buck-Morss (1989); Demetz, in his biographical introduction to the collection of Benjamin's essays (1986); and Benjamin himself in his autobiographical pieces like 'A Berlin Chronicle' (in 1986a).

44. In order to place myself in relation to this narrative it is worth adding that my father, Marcel Weisselberg, and his brother and sisters, born at the beginning of the century into the Vienna that Karl Kraus describes, also engaged in these domestic intergenerational Jewish struggles about the relative value of commerce and intellectual-political life.

45. It is also interesting in this context to refer back to Rudolph Hertzog's comments on the Selfridge's fifth anniversary 'Spirit of Modern Commerce' poster (see Note 23 above and and Fig 1). My only information about Hertzog is there in the text: he is the head of one of the greatest businesses in the German Empire and here in this letter of congratulations to Selfridges c1914 he rather poignantly regrets that the sons of successful merchants have no pride in commerce and prefer to devote themselves to academic or official careers. 'The merchant is himself to blame if he does not receive the respect he deserves, because frequently he lets his sons choose other careers and gives the impression that he considers other callings of more importance than his own.'

46. This book is of course an instance of how this has now started to change.

\section{References}

Abelson, Elaine (1989) When Ladies Go A-Thieving: Middle-Class Shoplifters in the Victorian Department Store, Oxford University Press.

Adburgham, Alison (1979) Shopping in Style: London from the Restoration to Edwardian Elegance, London: Thames and Hudson.

Adburgham, Alison (1989) Shops and Shopping 1800-1914, London: Barrie and Jenkins.

Addams, Jane (1910) The Spirit of Youth and the City Streets, New York: Macmillan.

Adorno, Theodore and Horkheimer, Max (1973) Dialectics of Enlightenment, London: Allen Lane.

Anderson, Perry (1984) 'Modernity and Revolution', New Left_Review No 144. 
Arendt, Hannah (1973) 'Introduction: Walter Benjamin 1892-1940' in Walter Benjamin's Illuminations,

London, Fontana.

Baudelaire, Charles (1965) The Painter of Modern Life and Other Essays, Oxford: Phaidon.

Bauman, Zygmunt (1983) 'Industrialism, Consumerism and Power' in Theory, Culture and Society, Vol 1/3.

Benjamin, Walter (1968) 'Paris - Capital of the Nineteenth Century', in New Left Review, No 48.

Benjamin, Walter (1973) Illuminations, London: Fontana.

Benjamin, Walter (1986a) Reflections, New York: Schocken Books.

Benjamin, Walter (1986b) Moscow Diary, Harvard University Press.

Berman, Marshall (1983) All That Is Solid Melts into Air: The Experience of Modernity, London: Verso.

Berman, Marshall (1984) 'The Signs in the Street: A Response to Perry Anderson', New Left Review No 124.

Bourdieu, Pierre (1986) Distinction: A Social Critique of the Judgement of Taste, London: Routledge \& Kegan Paul.

Bowlby, Rachel (1985) Just Looking: Consumer Culture in Dreiser, Gissing and Zola, London: Methuen.

Bradbury, Malcolm and McFarlane, James (eds.)(1987) Modernism 1890-1930, Harmondsworth: Penguin.

Brandon, Ruth (1990) The New Woman and the Old Men: Love, Sex and the Woman Question, London:

Flamingo.

Breward, Christopher (1994) 'Femininity and Consumption: The Problem of the Late Nineteenth Century Fashion Journal', Journal of Design History, June.

Brewster, Ben (1968) 'Walter Benjamin and the Arcades Project' in New Left Review No 48.

Buci-Glucksmann, Christine (1987) 'Catastrophic Utopia: The Feminine as Allegory of the Modern' in C. Gallagher and T. Laqueur (eds) The Making of the Modern Body University of California Press.

Buck-Morss, Susan (1983) 'Benjamin's Passagen-Werk: Redeeming Mass Culture for the Revolution', in New German Critique, No 29.

Buck-Morss, Susan (1989) The Dialectics of Seeing: Walter Benjamin and the Arcades Project, Place?: MIT Press.

Callery, Sean (1991) Harrods Knightsbridge: The Story of Society's Favourite Store, London: Ebury Press.

Campbell, Colin (1987) The Romantic Ethic and the Spirit of Modern Consumerism, Oxford: Blackwell.

Campbell, Colin and Falk, Pasi (eds) (1996) Shopping Experience, London: Sage.

Carter, Erica (1984) 'Alice in Consumer Wonderland' in A. McRobbie and M. Nava (eds) Gender and Generation, London: MacMillan.

Carter, Erica (1995) How German is She? National Reconstruction and the Consuming Woman in the FRG and West Berlin 1945-1960, University of Michigan Press. 
Chaney, David (1983) 'The Department Store as Cultural Form' Theory, Culture and Society, Vol 1/3.

Covina, Maurice (1978) Fine Silks and Oak Counters,: Debenhams 1778-1978, London: Hutchinson Benham.

Davidoff, Leonore (1973) The Best Circles: 'Society', Etiquette and the Season, London: Croom Helm.

Davidoff, Leonore, L'Esperance, Jean and Newby, Howard (1976) 'Landscape with Figures: Home and Community in English Society' in Mitchell and Oakley (eds) The Rights and Wrongs of Women,

Harmondsworth: Penguin.

Davidoff, Leonore and Hall, Catherine (1987) Family Fortunes: Men and Women of the English Middle Class 1780-1850, London: Hutchinson.

Davis, Dorothy (1966) A History of Shopping, London: Routledge \& Kegan Paul.

Demetz, Peter (1986) Introduction to Walter Benjamin's Reflections, New York: Schocken Books.

Donzelot, Jacques (1979) The Policing of Families, London: Hutchinson.

Dreiser, Theodore (1981) Sister Carrie, Harmondsworth: Penguin.

Eckert, Charles (1990) 'The Carole Lombard in Macy's Window', in J. Gaines and C. Herzog (eds)

Fabrications: Costume and the Female Body, London: Routledge.

Ewen Stuart (1976) Captains of Consciousness: Advertising and the Social Roots of Consumer Society, New York: McGraw Hill.

Ewen, Stuart and Ewen, Elizabeth (1982) Channels of Desire: Mass Images and the Shaping of American Consciousness, New York: McGraw Hill.

Ewen, Stuart (1988) All Consuming Images, New York: Basic Books.

Falk, Pasi (1996) 'For Your Eyes Only? The Scopic Regimes of Shopping' in C. Campbell and P. Falk (eds).

Featherstone, Mike (1983) 'Consumer Culture' in Theory, Culture and Society, Vol 1/3.

Forty, Adrian (1986) Objects of Desire, London: Thames and Hudson.

Foucault, Michel (1980) Power/Knowledge Brighton: Harvester.

Frei, Norbert (1987) National Socialist Rule in Germany: The Fuhrer State 1933-1945, Oxford:

Blackwell.

Frisby, David (1985) Fragments of Modernity: Georg Simmel, Siegfried Kracauer and Walter Benjamin, London: Heinemann.

Fromm, Bella (1943) Blood and Banquets: A Berlin Social Diary, London: Geoffrey Bles.

Gaines, Jane (1990) 'Fabricating the Female Body' in J. Gaines and C. Herzog (eds) Fabrications,

London: Routledge. 
Gramsci, Antonio (1973) 'Americanism and Fordism' in Prison Notebooks, London: Lawrence and Wishart.

Granville Barker, Harley (1977) The Madras House, London: Eyre Methuen.

Greenhalgh, Paul (1988) Ephemeral Vistas: The Expositions Universelles, Great Exhibitions and World's Fairs, 1951-1939, Manchester University Press.

Grossmann, Atina (1984) 'The New Woman and the Rationalisation of Sexuality in Weimar Germany' in A. Snitow et al (eds) Desire: The Politics of Sexuality, London: Virago.

Hake, Sabine (1987) 'Girls in Crisis' in New German Critique No 40.

Hansen, Miriam (1983) 'Early Silent Cinema: Whose Public Sphere' in New German Critique No 29.

Held, David (1980) Introduction to Critical Theory, London: Hutchinson.

Hollis, Patricia (1979) Women in Public: The Women's Movement 1850-1900, London: George Allen and Unwin.

Honeycombe, Gordon (1984) Selfridges, London: Park Lane Press.

Horkheimer, Max (1972) 'Authority and the Family' and 'Art and Mass Culture' both in his Critical Theory: Selected Essays, New York, Heider and Heider.

Horowitz, Daniel (1985) The Morality of Spending: Attitudes towards Consumer Society in America 1875-1940, Baltimore: John Hopkins University Press.

Huyssen, Andreas (1986) 'Mass Culture as Woman: Modernism's Other' in his After the Great Divide, London: Macmillan.

Jay, Martin (1984) Adorno, London: Fontana.

Jay, Martin (1992) 'Scopic Regimes of Modernity', in S. Lash and J. Friedman (eds) Modernity and Identity, Oxford: Blackwell.

Kohn, Marek (1992) Dope Girls: The Birth of the British Drug Underground, London: Lawrence and Wishart.

Kracauer, Siegfried (1987) 'The Cult of Distraction: On Berlin's Picture Palaces' in New German Critique No 40.

Kuhn, Annette (1988) Cinema, Censorship and Sexuality 1909-1925, London: Routledge.

Lancaster, William (1995) The Department Store: A Social History, London: Pinter.

Lasch, Christopher (1979) The Culture of Narcissism, New York: Norton.

Lash, Scott and Friedman, Jonathan (eds.) (1992) Modernity and Identity, Oxford: Blackwell.

Leach, William (1984) 'Transformations in a Culture of Consumption: Women and Department Stores, 1890-1925', The Journal of American History, Vol 7/2.

Marchand, Roland (1986) Advertising the American Dream: Making Way for Modernity 1920-1940, University of California Press. 
Marriott, John (1995) 'Sensation of the Abyss: The Urban Poor and Modernity' in Nava and O'Shea (eds) Modern Times: Reflections on a Century of English Modernity, London: Routledge.

Mast, Gerald (1982) The Movies in our Midst: Documents in the Cultural History of Film in America, University of Chicago Press.

McCracken, Grant (1990) Culture and Consumption, Indiana University Press.

McKendrick, John Brewer and J. H. Plumb (1982) The Birth of a Consumer Society: The Commercialisation of Eighteenth-Century England, London: Europa.

McRobbie, Angela (1992) 'The Passagenwerk and the Place of Walter Benjamin in Cultural Studies', in Cultural Studies, Vol 6/2.

Melman, Billie (1988) Women and the Popular Imagination in the Twenties, London: Macmillan.

Miller, Daniel (1996) 'Could Shopping Ever Really Matter?', in C. Campbell and P. Falk (eds) Shopping Experience, London: Sage.

Miller, Michael (1981) The Bon Marche: Bourgeois Culture and the Department Store 1869-1920, London: Allen and Unwin.

Mitchell, Juliet and Oakley, Anne (eds) (1976) The Rights and Wrongs of Women, Harmondsworth: Penguin.

Modleski, Tania (1986a) 'Femininity as Mas(s)querade: a Feminist Approach to Mass Culture' in C. McCabe (ed) High Theory/Low Culture, Manchester University Press (reprinted in Modleski 1991).

Modleski, Tania (ed) (1986b) Studies in Entertainment: Critical Approaches to Mass Culture, Indiana University Press.

Morris, Meaghan (1988) 'Things to do with Shopping Centres' in S. Sheridan (ed) Grafts, London: Verso.

Mort, Frank (1988) 'Boys Own? Masculinity, Style and Popular Culture', in R. Chapman and J.

Rutherford (eds) Male Order: Unwrapping Masculinity, London: Lawrence and Wishart.

Moss, Michael and Turton, Alison (1989) A Legend of Retailing: House of Fraser, London: Weidenfeld and Nicholson.

Nava, Mica (1984) 'The Urban, the Domestic and Education for Girls', in G. Grace (ed) Education and the City, London: Routledge \& Kegan Paul (reprinted in Nava 1992).

Nava, Mica (1992) Changing Cultures: Feminism, Youth and Consumerism, London: Sage.

Nava, Mica (1995) 'Modernity Tamed? Women Shoppers and the Rationalisation of Consumption in the Interwar Period', Australian Journal of Communication, Vol 22(2).

Nava, Mica and O'Shea, Alan (eds.) (1995) Modern Times: Reflections on a Century of English Modernity London: Routledge.

Nixon, Sean (1992) 'Have You Got the Look? Masculinities and Shopping Spectacle' in R Shields (ed) Life Style Shopping: The Subject of Consumption, London: Routledge. 
O'Shea, Alan (1995) 'English Subjects of Modernity' in M. Nava and A. O'Shea (eds) Modern Times: Reflections on a Century of English Modernity, London: Routledge.

Petro, Patrice (1987) 'Modernity and Mass Culture in Weimar' in New German Critique No 40.

Pollock, Griselda (1988) Vision and Difference, London: Routledge.

Poster, Mark (1978) Critical Theory of the Family, London: Pluto Press.

Pumphrey, Martin (1987) 'The Flapper, the Housewife and the Making of Modernity' in Cultural Studies Vol 1/2.

Richards, Jeffrey (1984) The Age of the Dream Palace: Cinema and Society in Britain 1930-1939,

London: Routledge.

Richards, Thomas (1991) The Commodity Culture of Victorian England: Advertising and Spectacle 1851-1914, London: Verso.

Robins, Elizabeth (1980) The Convert, London: The Women's Press.

Rose, Nikolas (1979) 'The Psychological Complex: Mental Measurement and Social Administration', in Ideology and Consciousness No 5.

Ross, Kirstin (1992) Introduction to Emile Zola Ladies' Paradise, University of California Press.

Ryan, Jenny (1992) Women, Modernity and the City, Working Papers in Popular Cultural Studies No 1, Manchester Institute for Popular Culture.

Sackville West, Vita (1983) The Edwardians, London: Virago.

Schudson, Michael (1984) Advertising the Uneasy Persuasion, New York: Basic Books.

Schwarz, Bill (1991) 'Rationalism, Irrationalism and Taylorism' in Science and Culture No 8.

Sennett, Richard (1986) The Fall of Public Man, London: Faber and Faber.

Shields, Rob (ed) (1992) Life Style Shopping: The Subject of Consumption, London: Routledge.

Showalter, Elaine (1992) Sexual Anarchy: Gender and Culture at the Fin de Siecle, London: Virago.

Simmel, Georg (1971) 'The Metropolis and Mental Life', in On Individuality and Social Forms,

University of Chicago Press.

Smith, Gary (1986) Afterword to Walter Benjamin's Moscow Diary, Harvard University Press.

Strachey, Ray (1978) The Cause, London: Virago.

Stedman Jones, Gareth (1976) Outcast London, Harmondsworth: Penguin.

Stein, Sally (1985) 'The Graphic Ordering of Desire: Modernisation of a Middle-Class Women's Magazine 1914-1939', Heresies No 18.

Theweleit, Klaus (1987) Male Fantasies, Cambridge: Polity.

Thonnessen, Werner (1973) The Emancipation of Women: Germany 1863-1933, London: Pluto Press. 
Tickner, Lisa (1987) The Spectacle of Women: Imagery of the Suffrage Campaign 1907-1914, London: Chatto and Windus.

Trimberger, Ellen (1984) 'Feminism, Men and Modern Love: Greenwich Village 1900-1935' in A.

Snitow et al (eds) Desire: The Politics of Sexuality, London: Virago.

Valverde, Mariana (1989) 'The Love of Finery: Fashion and the Fallen Woman in 19th Century Social Discourse' in Victorian Studies, Winter.

van Vucht Tijssen, Lieteke (1991) 'Women and Objective Culture: Georg Simmel and Marianne Weber' Theory, Culture and Society, Vol/3.

Veblen, Thorstein (1979) Theory of the Leisure Class, Harmondsworth: Penguin.

Vickery, Amanda (1992) 'Women and the World of Goods: A Lancashire Consumer and her Possessions 1751-81', in J. Brewer and R. Porter (eds), Consumption and the World of Goods, London: Routledge, 1992.

Vickery, Amanda (1993) 'Shaking the Separate Spheres' Times Literary Supplement March 12th.

von Rezzori, Gregor (1983) Memoirs of an Anti-Semite: A Novel in Five Stories, London: Pan Books.

Walkowitz, Judith (1980) Prostitution and Victorian Society, Cambridge University Press.

Walkowitz, Judith (1992) City of Dreadful Delight, London: Virago.

Ward, Ken (1991) Mass Communication and the Modern World, London: Macmillan.

Weeks, Jeffrey (1982) Sex. Politics and Society, London: Longman.

Williams, Raymond (1975) Country and City, Harmondsworth: Penguin.

Williams, Raymond (1989) The Politics of Modernism, London: Verso.

Williams, Rosalind (1982) Dream Worlds: Mass Consumption in Late Nineteenth-Century France, University of California Press.

Wilson, Elizabeth (1978) Women and the Welfare State, London: Tavistock.

Wilson, Elizabeth (1991) Sphinx in the City, London: Virago.

Wilson, Elizabeth (1992) 'The Invisible Flaneur' New Left Review No 191.

Wolff, Janet (1985) 'The Invisible Flaneuse: Women in the Literature of Modernity', Theory, Culture and Society Vol 2/3.

Wolff, Janet (1990) Feminine Sentences: Essays on Women and Culture, Cambridge: Polity.

Wolff, Janet (1993) 'Memoirs and Micrologies: Walter Benjamin, Feminism and Cultural Analysis' in New Formations No 20.

Wollen, Peter (1993) 'Modern Times: Cinema/Americanism/The Robot' in Raiding the Icebox:

Reflections on Twentieth Century Culture, London: Verso. 
Zola, Emile (1992) The Ladies' Paradise University of California Press.

Zukin, Sharon (1988) 'The Postmodern Debate over Urban Form' in Theory, Culture and Society Vol 5/23. 